\title{
Emission of iodine-containing volatiles by selected microalgae species
}

\author{
U. R. Thorenz ${ }^{1, *}$, L. J. Carpenter ${ }^{2}$, R.-J. Huang ${ }^{1,3,4}$, M. Kundel ${ }^{1}$, J. Bosle ${ }^{1}$, and T. Hoffmann ${ }^{1}$ \\ ${ }^{1}$ Institute of Inorganic and Analytical Chemistry, Johannes Gutenberg-University of Mainz, \\ 55128 Mainz, Germany \\ ${ }^{2}$ Department of Chemistry, University of York, Heslington, York YO10 5DD, UK \\ ${ }^{3}$ School of Physics \& Centre for Climate and Air Pollution Studies, Ryan Institute, \\ National University of Ireland Galway, University Road, Galway, Ireland \\ ${ }^{4}$ Laboratory of Atmospheric Chemistry, Paul Scherrer Institute (PSI), \\ 5232 Villigen, Switzerland \\ *now at: Max Planck Institute for Chemistry, 55128 Mainz, Germany
}

Correspondence to: T. Hoffmann (t.hoffmann@uni-mainz.de)

Received: 15 April 2014 - Published in Atmos. Chem. Phys. Discuss.: 5 June 2014

Revised: 4 November 2014 - Accepted: 17 November 2014 - Published: 15 December 2014

\begin{abstract}
In this study we present the results of an emission study of different phytoplankton samples in aqueous media treated with elevated ozone levels. Halocarbon measurements show that the samples tested released bromoform and different iodocarbons, including iodomethane, iodochloromethane and diiodomethane. Iodide and iodate levels in the liquid phase were representative of concentrations of surface water in a natural environment. Measurement of volatile iodine $\left(\mathrm{I}_{2}\right)$ emissions from two diatom samples (Mediopyxis helysia and Porosira glacialis) and the background sample (F/2 medium from filtered natural seawater) showed that the quantity of evolved $\mathrm{I}_{2}$ depends on the ozone concentration in the air. This behaviour was assumed to be caused by the oxidation reaction mechanism of iodide with ozone. The $\mathrm{I}_{2}$ emission flux agrees with model calculations at different iodide concentrations. The $\mathrm{I}_{2}$ emission of a natural plankton concentrate sample was, however, very low compared to other samples and showed no dependence on ozone. The reason for this was shown to be the low iodide concentration in the algal suspension, which seems to be the limiting factor in the oxidative formation of $\mathrm{I}_{2}$.
\end{abstract}

\section{Introduction}

Iodine chemistry plays an essential role in the marine boundary layer (MBL) due to its effect on the destruction of tropospheric ozone, perturbation of the $\mathrm{HO}_{\mathrm{x}}-\mathrm{NO}_{\mathrm{x}}$ cycle and the formation of new particles and cloud condensation nuclei, thereby leading to changes in the global radiative forcing (Hoffmann et al., 2001; von Glasow and Crutzen, 2003; O'Dowd and Hoffmann, 2005; Bloss et al., 2005; Huang et al., 2010a, b). This essential role of iodine and of other activated halogens is shown in field measurements in the marine boundary layer (MBL), laboratory chamber experiments or incubation experiments of different algae and in atmospheric models (Carpenter, 2003; Küpper et al., 2008; Kundel et al., 2012; McFiggans et al., 2000). The biogeochemical cycle of iodine is controlled by large iodine exchanges from the oceans to the atmosphere, driven by marine biotic and abiotic production (Schall et al., 1997). Volatilized species are photolabile iodocarbons like $\mathrm{CH}_{2} \mathrm{I}_{2}$, $\mathrm{CH}_{3} \mathrm{I}, \mathrm{C}_{2} \mathrm{H}_{5} \mathrm{I}, \mathrm{CH}_{2} \mathrm{ICl}, \mathrm{CH}_{2} \mathrm{IBr}$ and molecular iodine $\left(\mathrm{I}_{2}\right)$. Marine species like macroalgae and microalgae play a dominant role in the emission of these compounds (Carpenter et al., 1999; Huang et al., 2013; Saiz-Lopez and Plane, 2004). 
Since molecular iodine and iodocarbons are photochemically unstable (lifetimes between about some tens of seconds for $\mathrm{I}_{2}$ and a few days for $\mathrm{CH}_{3} \mathrm{I}$ ), they are photolysed under UV-visible light to form I. atoms, which are then instantly oxidized by ozone to form the iodine monoxide radical IO (g) (Hoffmann et al., 2001; Saiz-Lopez et al., 2006). Further oxidation reactions of IO in the gas phase then can form low-volatility iodine oxides $\left(\mathrm{I}_{\mathrm{x}} \mathrm{O}_{\mathrm{y}}\right)$ which may nucleate under certain conditions and form new particles.

Recently it was proposed that the ozone loss over the tropical Atlantic Ocean was higher than calculated from global atmospheric models, and that this additional ozone destruction is induced by halogens such as bromine and iodine (Read et al., 2008). Biogenic emissions, such as the already-studied iodocarbon emissions by phytoplankton species - e.g. coccolithophorids, diatoms and chlorophytes (Colomb et al., 2008) - are too low to explain the differences in model calculations and observations (Mahajan et al., 2010); therefore additional sources of the reactive iodine species are discussed, one of them being the surface reaction of ozone with seawater.

Garland and Curtis first discovered that the emission of molecular iodine from the surface of artificial and natural seawater is proportional to the ozone concentration at the airwater interface (Garland and Curtis, 1981). Sakamoto and co-workers examined the reaction mechanism of the iodide oxidation by ozone at the air-water interface, resulting in the formation of the intermediates $\mathrm{IOOO}^{-}$and HOI and the emission products IO and $\mathrm{I}_{2}$ (Sakamoto et al., 2009). Further laboratory experiments show that different organics affect the reaction of iodide with ozone; e.g. fulvic acid enhances the $\mathrm{I}_{2}$ formation but not the formation of IO (Hayase et al., 2010, 2012).

Since the formation of $I_{2}$ and IO from the air-water interface is dependent on the iodide concentration in seawater, the reaction path found by Garland and Curtis may explain elevated iodine emissions in areas of higher phytoplankton activity (Garland and Curtis, 1981). The ability of different phytoplankton, e.g diatoms, to reduce iodate, which is ubiquitous in the open ocean, to iodide was shown for natural and elevated iodate concentrations (Wong et al., 2002; Chance et al., 2007) and for the different growth states (Bluhm et al., 2010) of the phytoplankton cultures. A correlation of iodine species in the particle phase and average chlorophyll exposure of air masses along back trajectories was found by Lai et al. (2011), indicating the link between phytoplankton activity and emission of atmospheric iodine.

Since the formation of $\mathrm{I}_{2}$ and IO is correlated with the iodide concentration (Sakamoto et al., 2009) and the iodide concentration of surface waters is correlated with phytoplankton (Bluhm et al., 2010), this study investigates links between iodide concentrations in microalgae-containing seawater and abiotic formation and emission of $\mathrm{I}_{2}$, utilizing laboratory experiments of the reaction of the seawater surface with ozone.

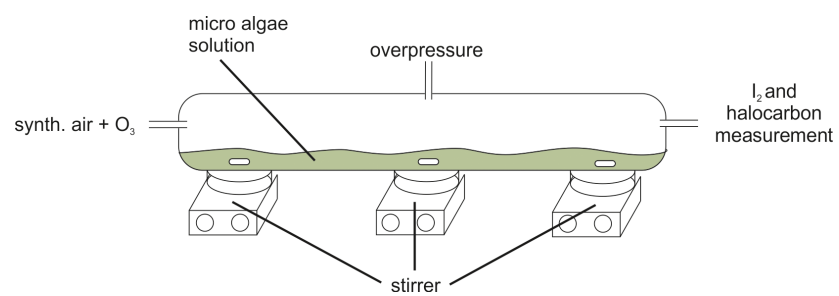

Figure 1. Experimental set-up of the chamber with the phytoplankton suspension.

\section{Materials and methods}

\subsection{Experimental set-up}

Two diatom cultures (M. helysia and Porosyra glacialis, both from the Alfred Wegener Institute/Sylt) were kept in F/2 seawater medium for growing. These media were prepared from filtered natural seawater from the shores of Sylt and additional nutrients which the diatoms need to grow $\left(0.88 \mathrm{mmol} \mathrm{NO}_{3}^{-}, 0.04 \mathrm{mmol} \mathrm{PO}_{4}^{3-}\right.$ and $\left.0.01 \mathrm{mmol} \mathrm{SiO}_{3}^{2-}\right)$ and which is a common used medium as described by Guillard et al. (1975) and Kraberg et al. (2012). Both cultures were incubated in the $\mathrm{F} / 2$ medium at $16{ }^{\circ} \mathrm{C}$ with $12 \mathrm{~h}$ light-12 $\mathrm{h}$ dark cycling (LUMILUX Plus Eco daylight lamp; ca. $40 \mu \mathrm{mol}$ PAR) for 4 weeks prior the experiment. Just before the emission experiment, the algal suspensions were diluted in a $2: 1$ ratio in $F / 2$ medium and homogenized by stirring. In addition to the diatom cultures, a plankton concentrate was collected from the North Sea $\left(55^{\circ} 01.562^{\prime} \mathrm{N}\right.$, $8^{\circ} 27.113^{\prime}$ E) on 24 May 2012 using a $80 \mu \mathrm{m}$ and $200 \mu \mathrm{m}$ Apstein plankton net and diluted using the same medium as for the diatom cultures. Microscopic observations showed that the plankton concentrate sample was dominated by colonies of the haptophyte Phaeocystis sp. and only a low amount of diatoms were present.

For each experiment $1.5 \mathrm{~L}$ of the sample (i.e. diatom suspension, natural plankton concentrate or background $(\mathrm{F} / 2$ medium)) was introduced into a glass chamber tube $(10 \mathrm{~L})$, shown in Fig. 1, and three magnetic stirrers were switched on immediately. A continuous flow of synthetic air (3.4 $\mathrm{L} \mathrm{min}^{-1}$ ) was channelled over the stirred algae suspension (surface area $2250 \mathrm{~cm}^{2}$ ) in the first experiment with no ozone and in the second experiment with elevated ozone levels of $100 \mathrm{ppb}$. The ozone was generated using an UV radiation source, and the resulting ozone levels were measured using an ozone analyser (Dasibi Environmental Corp. Model 1008-RS, Glendale, USA). To measure the emission of $\mathrm{I}_{2}$ and halocarbons, $\alpha$-cyclodextrin-coated denuders (Huang and Hoffmann, 2009; Huang et al., 2010c) and adsorption tubes (Kundel et al., 2012) were mounted at the other end of the tube chamber together with the ozone monitor. The chamber outflow was sampled using two membrane pumps, one with $0.50 \mathrm{~L} \mathrm{~min}^{-1}$ for the denuders and 
the other using $0.15 \mathrm{~L} \mathrm{~min}^{-1}$ for the adsorption tubes. To assure an overpressure over the sampling time, a U-shaped tube filled with ultrapure water was mounted in the centre exit of the glass chamber to measure the overpressure hydrostatically. The whole set-up was wrapped with aluminium foil to prevent photolysis of $\mathrm{I}_{2}$ and halocarbon compounds. Potential wall losses of $\mathrm{I}_{2}$ and halocarbons were investigated using diffusion $\left(\mathrm{I}_{2}\right)$ and permeation (halocarbons) test gas sources with a dilution chamber; no wall losses were observed within the precision of the measurements for the three concentrations tested $-70 \mathrm{ppt}, 270 \mathrm{ppt}$ and $700 \mathrm{ppt}$ for iodine and $0.2 \mathrm{ppt}, 2.4 \mathrm{ppt}$ and $8.3 \mathrm{ppt}$ for the halocarbons - within the stated gas flows.

To monitor the emissions of $I_{2}$ and halocarbons from the liquid samples, an evaporation standard was added to the microalgal suspension in order to highlight any problems related to air sampling. This standard was 1,3-dibromopropane diluted in ultrapure water $\left(500 \mu \mathrm{L}\right.$ of $0.94 \mu \mathrm{g} \mathrm{L}^{-1}$, which was then diluted with the sample to $1.5 \mathrm{~L}$ ). The standard was chosen given the results from a first set of experiments with $M$. helysia and Coscinodiscus wailesii which show no detectable traces of this compound. We decided not to add any iodinecontaining compounds to prevent interferences with the $\mathrm{I}_{2}$ emission.

\subsection{Halocarbon measurements}

Air samples of $6.75 \mathrm{~L}$ sampling volume were preconcentrated at a flow rate of $150 \mathrm{~mL} \mathrm{~min}^{-1}$ on thermal desorption tubes filled with $100 \mathrm{mg}$ Tenax TA 60/80 and $150 \mathrm{mg}$ Carbotrap ${ }^{\mathrm{TM}} 20 / 40$, both provided by Supelco (Bellefonte, PA, USA). The samples were analysed using a selfmade thermal desorption device mounted on a gas chromatograph (GC, TraceGC, Thermo Scientific, Dreieich Germany) and mass spectrometer (MS, PolarisQ, Thermo Scientific, Dreieich, Germany). During the desorption period of $6 \mathrm{~min}$ the cryotrap was cooled to $-160^{\circ} \mathrm{C}$. Afterwards the cryotrap was rapidly heated to $270^{\circ} \mathrm{C}$ for injection. The analytes were separated on a DB624 Durabond column $(60 \mathrm{~m}$; $0,32 \mathrm{~mm} ; 1,8 \mu \mathrm{m} \mathrm{FT}$ ) using helium as carrier gas with a constant pre-column pressure of $0.5 \mathrm{bar}$. The temperature program was $55^{\circ} \mathrm{C}(4 \mathrm{~min})$, ramp with $5^{\circ} \mathrm{C} \mathrm{min}{ }^{-1}$ to $120^{\circ} \mathrm{C}$ (4 min) and ramp with $8^{\circ} \mathrm{C} \mathrm{min}-1$ to $200^{\circ} \mathrm{C}(4 \mathrm{~min})$. Halocarbons were detected using a mass spectrometer in negative chemical ionization (NCI) mode with methane as reagent gas $\left(2.5 \mathrm{~mL} \mathrm{~min}^{-1}\right)$, the primary electron energy was set to $120 \mathrm{eV}$ and an emission current of $50 \mathrm{~mA}$ in single ion monitoring mode (SIM) was used. Iodinated compounds $\left(\mathrm{CH}_{3} \mathrm{I}, \mathrm{C}_{2} \mathrm{H}_{5} \mathrm{I}, \mathrm{CH}_{2} \mathrm{ICl}, \mathrm{CH}_{2} \mathrm{IBr}, \mathrm{CH}_{2} \mathrm{I}_{2}, 1-\mathrm{C}_{3} \mathrm{H}_{7} \mathrm{I}, 2-\mathrm{C}_{3} \mathrm{H}_{7} \mathrm{I}\right.$, 1-nC $\mathrm{n}_{4} \mathrm{H}_{9} \mathrm{I}, 2-\mathrm{nC}_{4} \mathrm{H}_{9} \mathrm{I}, 1$-iso- $\mathrm{C}_{4} \mathrm{H}_{9} \mathrm{I}$ ) were quantified using $m / z, 127$, and brominated compounds $\left(\mathrm{CH}_{2} \mathrm{Br}_{2}, \mathrm{CH}_{3} \mathrm{Br}, 1,3-\right.$ $\mathrm{C}_{3} \mathrm{H}_{6} \mathrm{Br}_{2}$ ) were quantified using $m / z, 79$ and 81 at a $1: 1$ ratio. A five-point calibration was done in the range between $0.01 \mathrm{ng}$ and $1 \mathrm{ng}$ using the continuously diluted output of a permeation test gas source (Thorenz et al., 2012). The de- tection limits for the individual iodocarbons were 0.003$0.088 \mathrm{ppt}$ and for the bromocarbons were $0.004-0.009 \mathrm{ppt}$. For each series of measurements, the calibration was done in triplicate (precision of method: 3-13\%).

\section{$2.3 \quad I_{2}$, iodide and iodate measurements}

Sampling of gaseous $\mathrm{I}_{2}$ was performed using the denuder technique described by Huang and Hoffmann (2009). Brown glass denuder tubes $(6 \mathrm{~mm}$ inside diameter, $50 \mathrm{~cm}$ length) were coated using an $\alpha$-cyclodextrin suspension (2.5 $\mathrm{mg} \mathrm{mL}^{-1}$ in methanol) and sealed with polypropylene caps. Before sampling the denuders were stored in a refrigerator. For sampling the denuders were mounted vertically with a glass tube of $15 \mathrm{~cm}$ upstream to achieve laminar flow. The sampling flow was $500 \mathrm{~mL} \mathrm{~min}^{-1}$ for $45 \mathrm{~min}$. After sampling the denuders were sealed and stored in a refrigerator until derivatization. For derivatization the $\alpha$-cyclodextrine coating was eluted with ultrapure water $(20 \mathrm{~mL})$; then $25 \mu \mathrm{L} \mathrm{N}, \mathrm{N}-$ dimethylaniline ( $1 \mu \mathrm{g} \mathrm{mL}^{-1}$ in methanol), $500 \mu \mathrm{L}$ phosphate buffer (pH 6.4) and $500 \mu \mathrm{L}$ 2-iodosobenzoate $\left(4 \mathrm{mg} \mathrm{mL}^{-1}\right)$ were added, and the mixture was shaken for $2 \mathrm{~h}$. After adding $3 \mathrm{~mL}$ sodium acetate, the sample was extracted with $100 \mu \mathrm{L}$ cyclohexane and $100 \mu \mathrm{L}$ 2,4,6-tribromoaniline (internal standard: IS) in cyclohexane ( $250 \mathrm{ppb})$.

Iodide and iodate were derivatized from seawater to form the same product as described for $\mathrm{I}_{2}$. Iodide was oxidized to form $\mathrm{I}_{2}$ by using iodosobenzoate, and iodate was reduced first to iodide and then oxidized to form $\mathrm{I}_{2}$. Ten-millilitre aliquots of seawater were analysed for iodide and for total iodine; iodate was calculated by difference. The method for iodide derivatization was slightly changed from the one described by Mishra et al. (2000). The use of sodium hydrogen sulfite as an agent to reduce iodate to iodide is described by Schwehr and Santschi (2003).

$\mathrm{I}_{\text {seawater }}=\mathrm{I}^{-}+\mathrm{IO}_{3}^{-}$

To measure iodide, $10 \mathrm{~mL}$ seawater was mixed with $1 \mathrm{~mL}$ ethylenediaminetetraacetic acid solution $(0.5 \%), 500 \mu \mathrm{L}$ phosphate buffer, $500 \mu \mathrm{L} \mathrm{N}, \mathrm{N}$-dimethylaniline and $500 \mu \mathrm{L}$ iodosobenzoate and shaken. After adding $3 \mathrm{~mL}$ sodium acetate the sample was extracted with $100 \mu \mathrm{L}$ cyclohexane and $100 \mu \mathrm{L}$ 2,4,6-tribromoaniline (IS) in cyclohexane (250 ppb).

To measure iodate an aliquot of $10 \mathrm{~mL}$ seawater was mixed with $1 \mathrm{~mL}$ ethylenediaminetetraacetic acid solution $(0.5 \%)$, $1 \mathrm{~mL}$ hydrochloric acid $(3.7 \%)$ and $500 \mu \mathrm{L}$ sodium hydrogen sulfite solution $\left(283.9 \mu \mathrm{mol} \mathrm{L}{ }^{-1}\right)$ to reduce the iodate. Afterwards $500 \mu \mathrm{L}$ sodium acetate, $4 \mathrm{~mL}$ phosphate buffer, $500 \mu \mathrm{L} \mathrm{N}, \mathrm{N}$-dimethylaniline and $500 \mu \mathrm{L}$ iodosobenzoate were added. After shaking the sample was again extracted with $100 \mu \mathrm{L}$ cyclohexane and $100 \mu \mathrm{L}$ 2,4,6-tribromoaniline (IS) in cyclohexane (250 ppb).

One microlitre of the cyclohexane extract was injected to the GC-MS system (6850 GC \& 5973 MS, Agilent Technologies, Waldbronn, Germany) at a constant flow of 
$1 \mathrm{~mL} \mathrm{~min}^{-1}$ of helium $(99.999 \%)$, and the chromatographic separation was performed using a capillary column FS Supreme $5 \mathrm{MS}$ with a length of $30 \mathrm{~m}$, inner diameter of $0.25 \mathrm{~mm}$ and film thickness of $0.25 \mu \mathrm{m}$ (CS Chromatographie Servieve, Langenwehe, Germany) with a temperature program starting at $50^{\circ} \mathrm{C}$ (for $3 \mathrm{~min}$ ), then heating up at $30^{\circ} \mathrm{C}$ $\min ^{-1}$ to $220^{\circ} \mathrm{C}$ (for $3 \mathrm{~min}$ ). The mass spectrometer measured in electron ionization mode at $70 \mathrm{eV}$; the specific fragments of the product 4-iodo-N,N-dimethylaniline was extracted at $m / z 247(\mathrm{M}+)$ and of the internal standard 2,4,6tribromoaniline at $m / z, 329(\mathrm{M}+)$.

\subsection{Chlorophyll measurements}

The analytical method for chlorophyll $a$ (Chl $a$ ) measurements is described by Edler et al. (1979). An aliquot of $50-100 \mathrm{~mL}$ water samples were filtered on glass fibre filters (Whatman, Grade GF/F). The dry filters were put in polypropylene vials and extracted with $7.5 \mathrm{~mL}$ acetone. The extract was stored together with the filter in a dark refrigerator at $3{ }^{\circ} \mathrm{C}$ overnight and centrifuged the next day $(5500 \mathrm{rpm}$, $7 \mathrm{~min}$ ) at $5^{\circ} \mathrm{C}$. The absorption of the supernatant was measured against acetone using an Uvikon XL double-beam spectrophotometer at $\lambda=750,663,645$ and $630 \mathrm{~nm}$. To calculate the concentration of Chl $a$ the equation of Jeffrey and Humphrey (1975) was used. Chl $a$ can be a good indicator for microalgae biomass (Roy 2010; Bluhm et al., 2010; Colomb et al., 2008) and has been used to calculated emission rates of iodine-containing volatiles from phytoplankton. This calculation was not used here, since the mechanisms of synthesis and release of these iodine-containing gases is still unclear. All gaseous compounds in this study are therefore given as measured mixing ratio, and the Chl $a$ value of the corresponding algae suspension is also given.

\section{Results and discussion}

\subsection{Halocarbons}

The emission rates of the natural halocarbons and the evaporation standard, given in Table 1, were calculated by the amount measured in the adsorption tubes divided by the emission time and the surface area of the suspension sample $\left(\mathrm{pmol} \mathrm{min} \mathrm{m}^{-1} \mathrm{~m}^{-2}\right.$ ). The halocarbon emission rates showed no effect on the different ozone levels; therefore the data for each sample are summarized for high- and low-ozone conditions. An evaporation standard was added to the different samples to recognize differences in emission rates of the organic compounds from the aqueous phase. The standard was added in a 10- to 100-fold excess compared to natural concentrations of bromocarbons in Atlantic seawater (Carpenter et al., 2000) to reduce the effect of natural 1,3-dibromopropane, which may alter the mixing ratio of the evaporation standard measured. In the chosen concentration a natural abundance would change the result only by $1-10 \%$ compared to the spike solution. The results of the measurements of 1,3-dibromopropane showed very constant values, as can be seen from the low standard deviation between the different samples and replicates. This result indicates a stable and reliable experimental set-up in terms of evaporation of volatile compounds from the water surface and of the mixing of the bulk water.

The measured emission rates of the natural halocarbons show that the brominated compound, $\mathrm{CHBr}_{3}$, is elevated compared to the iodocarbons emission rates. This result fits to observations of the natural abundance of halocarbons in seawater as described in earlier studies (Roy et al., 2011). The emission rate of $\mathrm{CHBr}_{3}$ is higher for the two diatom cultures (M. helysia and P. glacialis) than for the plankton samples containing Phaeocystis sp. and the background. Again, this result matches field and laboratory data showing a link between elevated $\mathrm{CHBr}_{3}$ concentrations in seawater and the simultaneous occurrence of diatoms (Colomb et al., 2008; Quack et al., 2007; Moore et al. 1996).

The iodocarbon emissions in experiments using the background (F/2 medium) and the plankton concentrate were dominated by $\mathrm{CH}_{3} \mathrm{I}$, followed by $\mathrm{CH}_{2} \mathrm{ICl}$ and $\mathrm{CH}_{2} \mathrm{I}_{2}$. However, for the diatom cultures, $\mathrm{CH}_{2} \mathrm{I}_{2}$ was the dominant iodocarbon emitted, with $\mathrm{CH}_{3} \mathrm{I}$ and $\mathrm{CH}_{2} \mathrm{ICl}$ both showing lower emission rates. The emission of iodocarbons from the F/2 background is not surprising for two reasons; first, the medium was produced from natural shoreline filtered water, which already may contain iodocarbons (Wong and Cheng, 1998). The second reason may be related to iodocarbon-producing bacteria (Amachi et al., 2001, 2003). These bacteria could have been present and active in the natural seawater used to produce the F/2 medium, since it was not sterilized prior to use. Additionally, the emission rates of $\mathrm{CH}_{2} \mathrm{I}_{2} \mathrm{CH}_{2} \mathrm{ICl}$ and $\mathrm{CH}_{3} \mathrm{I}$ in the diatom samples $P$. glacialis and $M$. helysia were significant higher compared to the background (Wilcoxon rank sum test $p=0.00032$ and $p=0.00007$, respectively). This increase in emission can be explained by the capability of the diatoms to produce iodocarbons, which had already been reported by Moore et al. (1996). To compare the natural plankton concentrate with the cultivated diatom cultures and the background, one must keep in mind that $\mathrm{Chl} a$ concentrations are biomass tracers reflecting the abundance of phytoplankton. The results for the Chl $a$ measurement, given in Table 1, clearly show that the natural plankton concentrate contains less biomass than the cultured diatoms. Therefore, we conclude that the lower iodocarbon emissions of the plankton concentrate compared to the diatom cultures is partly due to lower biomass density. The lower iodocarbon emission rates in the natural plankton concentrate could also be related to iodine uptake of naturally occurring microalgae (van Bergeijk et al., 2013). The emission flux summed for the three iodocarbons in the four samples' background, plankton concentrate, $P$. glacialis and $M$. helysia, was in the range $0.21-$ $1.02,0.14-0.58,0.50-1.35$ and $0.57-1,53 \mathrm{pmol} \mathrm{min}^{-1} \mathrm{~m}^{-2}$, 
Table 1. Halocarbon emission rates, concentrations of chlorophyll $\alpha$, iodide and iodate in the four different sample suspensions.

\begin{tabular}{|c|c|c|c|c|c|}
\hline Sample & & $\mathrm{F} / 2$ medium background & P. glacialis & M. helysia & Plankton concentrate \\
\hline & & Range (Mean) & Range (Mean) & Range (Mean) & Range (Mean) \\
\hline $\mathrm{CH}_{3} \mathrm{I}$ & pmol min $\min ^{-1}$ & $0.17-0.72(0.35)$ & $0.21-0.69(0.45)$ & $0.32-0.82(0.53)$ & $0.08-0.37(0.19)$ \\
\hline $\mathrm{CH}_{2} \mathrm{ICl}$ & pmol min ${ }^{-1} \mathrm{~m}^{-2}$ & $0.02-0.22(0.11)$ & $0.02-0.22(0.16)$ & $0.04-0.22(0.18)$ & $0.02-0.12(0.07)$ \\
\hline $\mathrm{CH}_{2} \mathrm{I}_{2}$ & pmol $\min ^{-1} \mathrm{~m}^{-2}$ & $0.02-0.08(0.07)$ & $0.27-0.44(0,36)$ & $0.21-0.50(0.37)$ & $0.04-0.09(0.07)$ \\
\hline $\mathrm{CHBr}_{3}$ & pmol $\min ^{-1} \mathrm{~m}^{-2}$ & $1.76-1.90(1.81)$ & $1.99-2.17(2.09)$ & $1.75-2.17(2.09)$ & $1.75-2.33(1.82)$ \\
\hline Chl $a$ & $\mu g \mathrm{~L}^{-1}$ & n.d. & 257 & 927 & 2.5 \\
\hline Iodide & $\mathrm{nmol} \mathrm{L}-1$ & $6.6-15.6(10.4)$ & $7.3-19.7(12.7)$ & $9.9-21.9(16.8)$ & $3.5-9.5(6.5)$ \\
\hline Iodate & $\mathrm{nmol} \mathrm{L}^{-1}$ & $402-538(428)$ & $408-478(448)$ & $397-499(446)$ & $424-478(442)$ \\
\hline $1,3-\mathrm{C}_{3} \mathrm{H}_{6} \mathrm{Br}_{2}^{*}$ & pmol min ${ }^{-1} \mathrm{~m}^{-2}$ & $7.77 \pm 0.04$ & $7.78 \pm 0.59$ & $7.77 \pm 0.99$ & $7.69 \pm 0.07$ \\
\hline$\Sigma_{\text {Iodocarbon/Chl a }}$ & $\mathrm{pmol} / \mathrm{g}$ & n.d. & 19.75 & 6.06 & 694.88 \\
\hline
\end{tabular}

* Evaporation standard given as mean \pm standard deviation.

$\mathrm{Chl} a$ was measured for each sample once halocarbons, iodide, iodate mean values and ranges had been calculated from six replicates $\Sigma_{\text {Iodocarbon/Chl a }}$. Iodocarbon emissions were summed for the eperimetntal conditions (time and surface area) and normalized to $\mathrm{Chl} a$ in the watery phase.

respectively. We are not aware of emission studies investigating the flux of iodocarbons from microalgae suspensions to directly compare these results. To establish a connection to other experimental observations, the results listed above are compared to incubation studies of marine aggregates producing iodocarbons and calculated emission fluxes in coastal, seaweed-rich regions. Hughes et al. (2008) measured the iodocarbon production of different marine aggregates to be within 0.71 to $6.90 \mathrm{pmol} \mathrm{h}^{-1} \mathrm{~L}^{-1}$. The production rate is difficult to compare to the presented results, since the flux in our study is based on the production by the microalgae species and evaporation from the surface, whereas Hughes et al. (2008) measured the production in the aqueous phase. Jones et al. (2009) calculated iodocarbon emissions at a sampling site surrounded by fields of macro algae in open-sea water at Roscoff, France. The flux of iodocarbons was estimated to $85.28 \mathrm{pmol} \mathrm{min}^{-1} \mathrm{~m}^{-2}, 2$ orders of magnitude higher than the flux obtained in the present study. Thus it appears that on an areal basis the natural populations of microalgae studied here are much less prevalent emitters of iodocarbons than seaweeds and marine aggregates.

\subsection{Iodide and iodate}

The concentrations of iodide and iodate in the different samples are shown in Table 1. For each sample, the mean and range for six replicates are shown; no differences in iodide and iodate concentrations were observed under elevated$\left(100 \mathrm{ppb} \mathrm{O}_{3}\right)$ and low-ozone $\left(0 \mathrm{ppb} \mathrm{O}_{3}\right)$ conditions. The iodate concentrations in the background and in the three plankton samples were in the same range, with mean concentrations between 438 and $448 \mathrm{nmol} \mathrm{L}^{-1}$. These iodate concentrations are in the range measured for the open ocean of 400 to $500 \mathrm{nmol} \mathrm{L}^{-1}$ iodate in most oceanic regions (Bluhm et al., 2011). The ubiquity of iodate suggests that its concentration is not a limiting factor.
The iodide concentrations in the two diatom cultures, $P$. glacialis and $M$. helysia, are slightly elevated, with mean values of $12.70 \mathrm{nmol} \mathrm{L}^{-1}$ and $16.84 \mathrm{nmol} \mathrm{L}^{-1}$, respectively, compared to the background iodide concentration of $10.35 \mathrm{nmol} \mathrm{L}^{-1}$ and the plankton concentrate iodide concentration of $6.47 \mathrm{nmol} \mathrm{L}^{-1}$. This enhanced iodide concentration indicates the reduction of iodate by the two diatom cultures, which was also found by Bluhm et al. (2010) and Wong et al. (2002) for different phytoplankton species. Such a reduction of iodate to iodide will result in a decrease in the iodate concentration; however, for the measured iodate concentration in this study the expected decrease falls within the analytical precision of the measurement. The iodide concentrations in all samples are comparable with oceanic surface water concentrations, for example around $10-30 \mathrm{nmol} \mathrm{L}^{-1}$ in the Weddel Sea surface water (Bluhm et al., 2011).

The low iodide concentration of the plankton concentrate sample compared to the background sample is surprising but may be assigned to an overall low level of different nutrients, like phosphate and silicate, in the Wadden Sea of Sylt during springtime (Weisse et al., 1986), although the level of iodate was consistent. Another possible reason for the low iodide concentration in the plankton concentrate could be iodine uptake by microalgae present in the natural plankton sample (van Bergeijk et al., 2013).

\subsection{Ozone measurements}

The results of the ozone measurement for the samples' background, $P$. glacialis, $M$. helysia and the plankton concentrate were normalized against a background measurement obtained using ultrapure water in the chamber. This was performed in order to account for losses of ozone through wall reactions, losses on the water surface and losses due to droplet formation from stirring. The ozone consumption was calculated using a continuous stirred-tank reactor (CSTR)

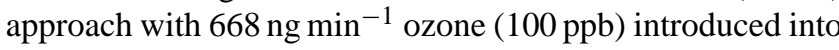




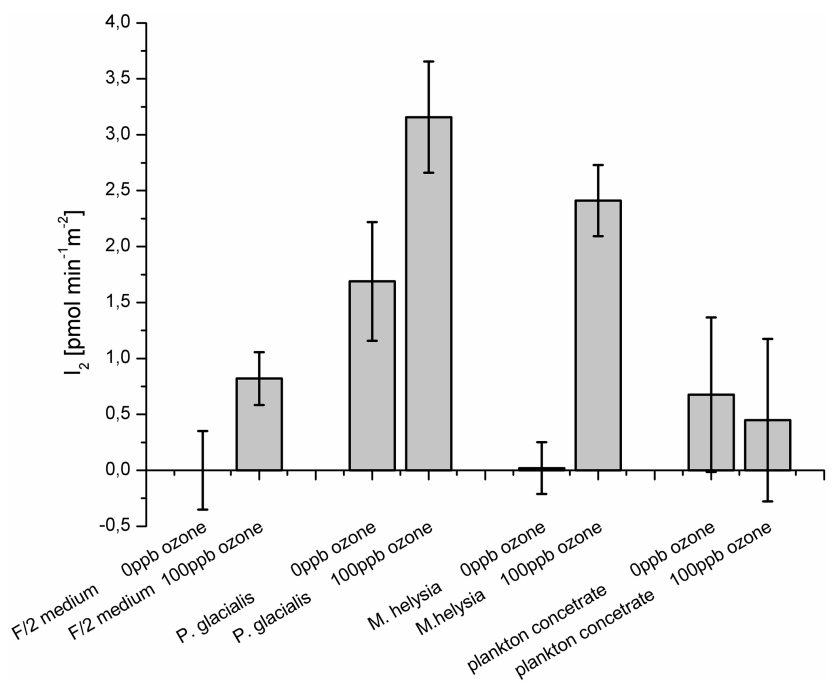

Figure 2. Iodine emission rates normalized for the surface area of the different samples at 0 and $100 \mathrm{ppb}$ ozone. The error bars represent the standard deviation of the three replicates of each experiment.

the chamber (total volume: $10 \mathrm{~L}$; flow: $3.4 \mathrm{~L} \mathrm{~min}^{-1}$; and residence time: $2.94 \mathrm{~min}$ ). The difference between the introduced ozone flow and measured ozone flow is considered as consumed ozone, due to the oxidation of iodide and other ozone-depleting reactions in the samples. To calculate the consumed ozone, the flow rate was summarized over $45 \mathrm{~min}$ of the experiment. Ozone consumption was clearly observed for all samples. The background sample showed the weakest ozone consumption of $58 \mathrm{nmol}$, followed by the sample of $P$. glacialis with $186 \mathrm{nmol}$ and the plankton concentrate with $253 \mathrm{nmol}$. The highest ozone consumption was shown by $M$. helysia with $335 \mathrm{nmol}$.

\section{$3.4 \quad I_{2}$ emissions}

The $\mathrm{I}_{2}$ emission rate was calculated by dividing the amount of $\mathrm{I}_{2}$ by the sampling time and the suspension surface area. The results for the four samples are shown in Fig. 2. The background and the two diatom samples, $M$. helysia and $P$. glacialis, show significantly higher emission rates when the ozone level is elevated $\left(100 \mathrm{ppb} \mathrm{O}_{3}\right)$ compared to conditions where no ozone is present $\left(0 \mathrm{ppb} \mathrm{O}_{3}\right)$. The difference between the high- and low-ozone conditions is small for the background, increases for the $P$. glacialis sample and is highest for the M. helysia sample. The plankton concentrate does not show a significant dependence of the $\mathrm{I}_{2}$ emission rate on the ozone level. The ozone-dependent increase in the $\mathrm{I}_{2}$ emission rate of the other samples indicates that iodide, which is present at the air-water interface, is oxidized by ozone to form $\mathrm{I}_{2}$, which is consistent with the results from artificial and natural seawater (Garland and Curtis, 1981; Sakamoto et al., 2009).

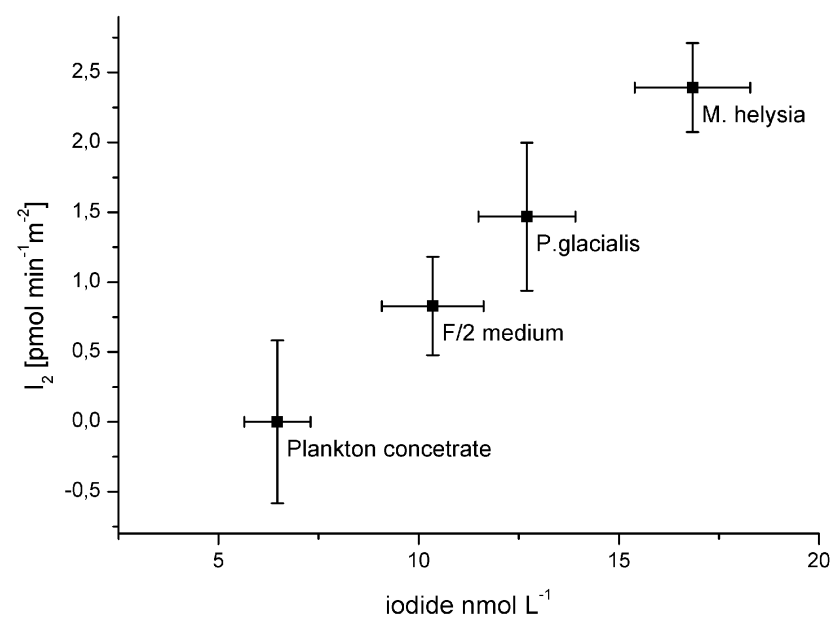

Figure 3. Correlation of the change in the $I_{2}$ emission and the iodide concentration in the microalgae suspension.

Figure 3 shows the change in $\mathrm{I}_{2}$ emission rate ([ $\mathrm{I}_{2}$ at $100 \mathrm{ppb}$ ozone $]-\left[\mathrm{I}_{2}\right.$ at $0 \mathrm{ppb}$ ozone $]$ ) of the different samples as a function of the iodide concentration measured in the bulk water. A linear correlation fits the data well with a Pearson's coefficient of $R^{2}=0.998$. This behaviour indicates a direct proportional relationship, which was also seen by Sakamoto et al. (2009) for small iodide concentrations ( 0 $5 \mathrm{mmol} \mathrm{L}^{-1}$ ). Carpenter et al. (2013) also observed that the $\mathrm{I}_{2}$ emission is dependent on the aqueous iodide concentration. The proposed reaction sequence, as shown in Eqs. (15), explains the relationship between the iodide concentration in the aqueous phase and the $\mathrm{I}_{2}$ emissions (Sakamoto et al., 2009).

$$
\begin{array}{r}
\mathrm{I}^{-}(\mathrm{aq})+\mathrm{O}_{3}(\mathrm{~g} \text { or interface }) \rightarrow \mathrm{IOOO}^{-} \text {(interface) } \\
\left.\mathrm{IOOO}^{-} \text {(interface }\right) \rightarrow \mathrm{IO}^{-}(\mathrm{aq})+\mathrm{O}_{2}(\mathrm{aq}) \\
\mathrm{IO}^{-}(\mathrm{aq})+\mathrm{H}^{+} \leftrightarrow \mathrm{HOI}(\mathrm{aq}) \\
\mathrm{HOI}(\mathrm{aq})+\mathrm{I}^{-}(\mathrm{aq})+\mathrm{H}^{+} \leftrightarrow \mathrm{I}_{2}(\mathrm{aq})+\mathrm{H}_{2} \mathrm{O} \\
\mathrm{I}_{2}(\mathrm{aq}) \rightarrow \mathrm{I}_{2}(\mathrm{~g})
\end{array}
$$

The plankton sample does not show an elevated $I_{2}$ emission at $100 \mathrm{ppb}$ ozone compared to zero ozone. This observation indicates that in the plankton sample an additional $\mathrm{I}_{2}$ loss process takes place. Reactions or partitioning of $I_{2}$ in an organic surface layer, which was discussed in Carpenter et al. (2013), would be one possibility to explain these results. In fact the specific microalga found in the plankton concentrate, Phaeocystis sp., is known to produce high amounts of organic matter (Eberlein et al., 1985). An alternative explanation is the low iodide concentration in the plankton concentrate, which may be related to iodide uptake by the naturally occurring plankton communities. The iodide concentrations and ozone mixing ratios in this study represent more likely natural conditions compared to the study of Sakamoto et al. (iodide concentration from 0.01 to $50 \mathrm{mmol} \mathrm{L}^{-1}$ and ozone mixing ratio from 2 to $298 \mathrm{ppm}$ ). However, the results 


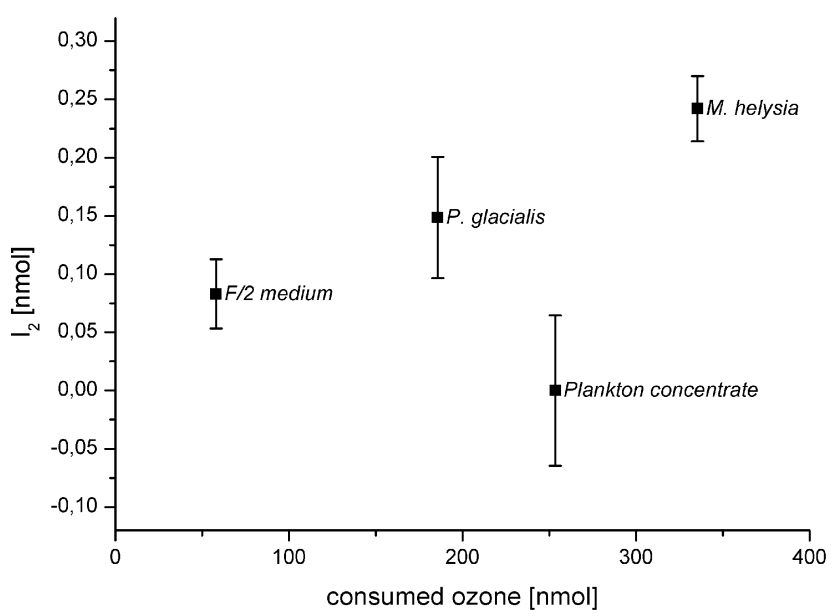

Figure 4. Function of the change in the total $\mathrm{I}_{2}$ emissions in relation to the amount of consumed ozone.

presented here demonstrate that, even under low iodide concentrations, representative of natural conditions of the MBL, a significant formation of $\mathrm{I}_{2}$ by the ozone driven oxidation of iodide at the air-water interface takes place, until the iodide concentration gets too low.

Comparing the $I_{2}$ and iodocarbon emission rates, it is clear that the volatile iodine emissions are dominated by $\mathrm{I}_{2}$. Therefore $\mathrm{I}_{2}$ emissions from natural seawater surfaces are more relevant for atmospheric processes than the emission of iodocarbons. At the same time the experiments presented here show that the emission of iodocarbons is not linked to the formation of $\mathrm{I}_{2}$ at the air-water interface (Martino et al., 2009), since no correlation between $\mathrm{I}_{2}$ emissions or $\mathrm{O}_{3}$ mixing ratio and iodocarbon emissions was observed.

Calculated emissions for the background, P. glacials and $M$. helysia were $8.32 \times 10^{5}, 1.47 \times 10^{6}$ and $2.40 \times 10^{6}$ molecules $\mathrm{cm}^{-2} \mathrm{~s}^{-1}$, respectively. Modelled emissions calculated using the kinetic model of the aqueous interfacial layer by Carpenter et al. (2013) for the iodide concentration measured were $1.16 \times 10^{6}, 1.67 \times 10^{6}$ and $2.91 \times 10^{6}$ molecules $\mathrm{cm}^{-2} \mathrm{~s}^{-1}$, respectively. The measured and modelled values agree well, showing that the model is able to predict emissions for natural iodide concentrations.

Figure 4 shows the change in the $I_{2}$ emission rate plotted versus the consumed ozone for the four different samples. This was done to see whether ozone depletion in the flow chamber is mainly driven by the iodide or whether other factors are important. The graph shows that the ozone depletion correlates with the enhancement in the $\mathrm{I}_{2}$ emission rate for the two diatom samples and for the background. Therefore, the ratio of the formation of $\mathrm{I}_{2}$ to the amount of $\mathrm{O}_{3}$ consumed - calculated as $R\left(\mathrm{I}_{2}\right)=n\left(\mathrm{I}_{2}\right) / n\left(\mathrm{O}_{3}\right)$, with $n\left(\mathrm{I}_{2}\right)=$ amount of $\mathrm{I}_{2}$ formed and $n\left(\mathrm{O}_{3}\right)=$ amount of $\mathrm{O}_{3}$ consumed during the experiment - was used to determine the dependence of $\mathrm{I}_{2}$ formation on $\mathrm{O}_{3} \cdot R\left(\mathrm{I}_{2}\right)$ has a maximum value of 1 , which, referring to Eqs. (1-5), indicates that every molecule of ozone which is consumed produces one molecule of $I_{2}$. The formation ratio for the background sample was the highest with $R\left(\mathrm{I}_{2}\right)=0.14 \%$, followed by the samples of $M$. helysia with $R\left(\mathrm{I}_{2}\right)=0.08 \%$ and $P$. glacialis $R\left(\mathrm{I}_{2}\right)=0.07 \%$. This means that a higher degree of biological activity of the sample decreases the formation ratio. The decrease of $\mathrm{I}_{2}$ emission in the surface reaction of ozone with iodide was also seen by Carpenter et al. when turning from iodide solutions to seawater, which contains more organic substances (Carpenter et al., 2013).

The plankton concentrate also depletes ozone, although there is no enhancement in $\mathrm{I}_{2}$ emission. Therefore, another mechanism in ozone depletion must be taking place, possibly induced by other ozone-reactive substances formed or excreted from Phaeocystis sp. Another explanation is a reduced release of $I_{2}$ and a higher release of HOI, which was not measured in this study. In fact, Carpenter and co-workers observed HOI to be the main iodine compound released in their experiments, followed by $\mathrm{I}_{2}$ (Carpenter et al., 2013).

\section{Conclusions}

Different phytoplankton suspensions were treated with high and low ozone levels. Halocarbons including bromoform, iodomethane, iodochloromethane and diiodomethane were released from the suspensions independent of the ozone level. The use of an evaporation standard in the aqueous phase indicated that the emission rates of all gaseous organics were quite stable. The iodide and iodate concentration in the liquid phase also showed no dependence on the ozone level in the gas phase and were comparable to concentrations in surface water in the open ocean. The emission flux of the iodocarbons was lower compared to the calculated flux at a coastal, kelp-rich site in Roscoff, France, an observation which emphasizes the higher emission of iodocarbons from macroalgae compared to microalgae. The emission rates of iodocarbons were also lower than the emission of $\mathrm{I}_{2}$, confirming that $\mathrm{I}_{2}$ emissions from the remote ocean dominate over organic iodine sources for the MBL (Jones et al., 2010; Lawler 2012; Carpenter et al., 2013). The emission of $\mathrm{I}_{2}$ showed a dependency on the ozone level in the air as well as on the iodide concentration in the sample suspension, as has been found previously (e.g. Carpenter et al., 2013). For the two diatom samples, $M$. helysia and $P$. glacialis, and the background sample, a correlation was found for the $\mathrm{I}_{2}$ emission and the ozone consumption during the experiment. The $\mathrm{I}_{2}$ emissions from the plankton concentrate, taken in the Wadden Sea of Sylt, were lower than the other samples and showed no dependence on the ozone levels. An explanation could be the lower iodide concentration in the plankton sample, since iodide is the limiting factor for the oxidative reaction. Another explanation may be the preferred formation and emission of HOI when organic compounds are present in the liquid phase. The experiments showed that different al- 
gae suspensions (M. helysia and P. glaciales) are capable of emitting $I_{2}$ by the reaction of ozone with dissolved iodide at the air-water interface under natural conditions. However, it remains unclear whether iodine emissions from aquatic systems can be fully understood without the simultaneous measurement of HOI.

Acknowledgements. The authors gratefully acknowledge the finical support of the German Research Foundation (DFG: Deutsche Forschungsgemeinschaft) within the Research Training Group 826: "Trace Analysis of Elemental Species: Development of Methods and Applications."

Edited by: H. Saathoff

\section{References}

Amachi, S., Kanagawa, T., and Muramatsu, Y.: Bacteria mediate methy lation of iodine in marine and terrestrial environments, Appl. Environ. Microbiol., 67, 2718-2722, 2001.

Amachi, S., Kasahara, M., Hanada, S., Kamagata, Y., Shinoyama, H., Fujii, T., and Muramatsu, Y.: Microbial participation in iodine volatilization from soils, Environ. Sci. Tech. 37, 3885-3890 2003.

Bloss, W. J., Lee, J. D., Johnson, G. P., Sommariva, R., Heard, D. E., Saiz-Lopez, A., Plane, J. M., McFiggans, G., Coe, H., Flynn, M., Williams, P., Rickard, A. R., and Fleming, Z. L.: Impact of halogen monoxide chemistry upon boundary layer $\mathrm{OH}$ and $\mathrm{HO}_{2}$ concentrations at a coastal site, Geophys. Res. Lett., 32, L06814, doi:10.1029/2004GL022084, 2005.

Bluhm, K., Croot, P., Wuttig, K., and Lochte, K.: Transformation of iodate to iodide in marine phytoplankton driven by cell senescence, Aquat. Biol., 11, 1-15, 2010.

Bluhm, K., Croot, P. L., and Huhn, O. R. G.: Distribution of iodide and iodate in the Atlantic sector of the southern ocean during austral summer, Deep-Sea Res. Pt. II, 58, 2733-2748, 2011.

Carpenter, L. J.: Iodine in the marine boundary layer, Chem. Rev., 103, 4953-4962, 2003.

Carpenter, L. J., Sturges, W. T., Penkett, S. A., Liss, P. S., Alicke, B., Hebestreit, K., and Platt, U.: Short-lived alkyl iodides and bromides at Mace Head, Ireland: links to biogenic sources and halogen oxide production, J. Geophys. Res.-Atmos., 104, 1679-1689, 1999.

Carpenter, L. J., Malin, G., Liss, P. S., and Kupper, F. C.: Novel biogenic iodine-containing trihalomethanes and other short-lived halocarbons in the coastal East Atlantic, Global Biogeochem. Cy., 14, 1191-1204, 2000.

Carpenter, L. J., MacDonald, S. M., Shaw, M. D., Kumar, R., Saunders, R. W., Parthipan, R., Wilson, J., and Plane, J. M. C.: Atmospheric iodine levels influenced by sea surface emissions of inorganic iodine, Nat. Geosci., 6, 108-111, 2013.

Chance, R., Malin, G., Jickells, T., and Baker, A. R.: Reduction of iodate to iodide by cold water diatom cultures, Mar. Chem., 105, 169-180, 2007.

Colomb, A., Yassaa, N., Williams, J., Peeken, I., and Lochte, K.: Screening volatile organic compounds (VOCs) emissions from five marine phytoplankton species by head space gas chromatography/mass spectrometry (HS-GC/MS), J. Environ. Monit., 10, 325-330, 2008.

Eberlein, K., Leal, M. T., Hammer, K. D., Hickel, W.: Dissolved organic substances during a Phaeocystis pouchetii bloom in the German Bight (North Sea), Mar. Biol., 89, 311-316, 1985.

Edler, L.: Phytoplankton and Chlorophyll. Baltic Marine Biologists, vol 5, Univ. of Stockholm, Stockholm, 1979.

Garland, J. A. and Curtis, H.: Emission of iodine drom the seasurface in the presence of ozone, J. Geophys. Res.-Oc. Atm., 86, 3183-3186, 1981.

Hayase, S., Yabushita, A., Kawasaki, M., Enami, S., Hoffmann, M. R., and Colussi, A. J.: Heterogeneous reaction of gaseous ozone with aqueous iodide in the presence of aqueous organic species, J. Phys. Chem. A, 114, 6016-6021, 2010.

Hayase, S., Yabushita, A., and Kawasaki, M.: Iodine emission in the presence of humic substances at the water's surface, J. Phys. Chem., 116, 5779-5783, 2012.

Hoffmann, T., O’Dowd, C. D., and Seinfeld, J. H.: Iodine oxide homogeneous nucleation: an explanation for coastal new particle production, Geophys. Res. Lett., 28, 1949-1952, 2001.

Huang, R. J. and Hoffmann, T.: Development of a coupled diffusion denuder system combined with gas chromatography/mass spectrometry for the separation and quantification of molecular iodine and the activated iodine compounds iodine monochloride and hypoiodous acid in the marine atmosphere, Anal. Chem., 81, 1777-1778, 2009.

Huang, R.-J., Seitz, K., Buxmann, J., Pöhler, D., Hornsby, K. E., Carpenter, L. J., Platt, U., and Hoffmann, T.: In situ measurements of molecular iodine in the marine boundary layer: the link to macroalgae and the implications for $\mathrm{O}_{3}, \mathrm{IO}, \mathrm{OIO}$ and $\mathrm{NO}_{\mathrm{x}}$, Atmos. Chem. Phys., 10, 4823-4833, doi:10.5194/acp-10-48232010, 2010a.

Huang, R. J., Seitz, K., Neary, T., O’Dowd, C. D., Platt, U., and Hoffmann, T.: Observations of high c oncentrations of $\mathrm{I}_{2}$ and IO in coastal air supporting iodine-oxide driven coastal new particle formation, Geophys. Res. Lett., 37, L03803, doi:10.1029/2009GL041467, 2010b.

Huang, R. J., Hou, X. L., and Hoffmann, T.: Extensive evaluation of a diffusion denuder for the quantification of atmospheric stable and radioactive molecular iodine, Environ. Sci. Technol., 44, 5061-5066, 2010c.

Huang, R.-J., Thorenz, U. R., Kundel, M., Venables, D. S., Ceburnis, D., Ho, K. F., Chen, J., Vogel, A. L., Küpper, F. C., Smyth, P. P. A., Nitschke, U., Stengel, D. B., Berresheim, H., O'Dowd, C. D., and Hoffmann, T.: The seaweeds Fucus vesiculosus and Ascophyllum nodosum are significant contributors to coastal iodine emissions, Atmos. Chem. Phys., 13, 5255-5264, doi:10.5194/acp-13-5255-2013, 2013.

Hughes, C., Malin, G., Turley, C., Keely, B., Nightingale, P., and Liss, P.: The production of volatile iodocarbons by biogenic marine aggregates. Limnol. Oceanogr., 53, 867-872, 2008.

Jeffrey, S. W. and Humphrey, G. F.: New spectrosphotometric equations for determining chlorophylls A, B, C1 and C2 in higher plants, algae and natural phytoplankton, Biochem. Physiol. Pfl., 167, 191-194, 1975.

Jones, C. E., Hornsby, K. E., Dunk, R. M., Leigh, R. J., and Carpenter, L. J.: Coastal measurements of short-lived reactive iodocarbons and bromocarbons at Roscoff, Brittany during 
the RHaMBLe campaign, Atmos. Chem. Phys., 9, 8757-8769, doi:10.5194/acp-9-8757-2009, 2009.

Kraberg, A., Carstens, K., Peters, S., Tilly, K., and Wiltshire, K.: The diatom Mediopyxis helysia Kühn, Hargreaves \& Halliger 2006 at Helgoland Roads: a success story? Helgoland Marine Research, 66, 463-468, doi:10.1007/s10152-011-0277-9, 2012.

Kundel, M., Thorenz, U. R., Petersen, J. H., Huang, R., Bings, N. H., and Hoffmann, T.: Application of mass spectrometric techniques for the trace analysis of short-lived iodinecontaining volatiles emitted by seaweed, Anal. Bioanal. Chem., 402, 3345-3357, 2012.

Küpper, F. C., Carpenter, L. J., McFiggans, G. B., Palmer, C. J., Waite, T. J., Boneberg, E., Woitsch, S., Weiller, M., Abela, R., Grolimund, D., Potin, P., Butler, A., Luther, G. W., Kroneck, P. M. H., Meyer-Klaucke, W., and Feiters, M. C.: Iodide accumulation provides kelp with an inorganic antioxidant impacting atmospheric chemistry, P. Natl. Acad. Sci. USA, 105, 6954-6958, 2008.

Lai, S. C., Williams, J., Arnold, S. R., Atlas, E. L., Gebhardt, S., and Hoffmann, T.: Iodine containing species in the remote marine boundary layer: a link to oceanic phytoplankton, Geophys Res. Lett., 38, L20801, doi:10.1029/2011GL049035, 2011.

Mahajan, A. S., Plane, J. M. C., Oetjen, H., Mendes, L., Saunders, R. W., Saiz-Lopez, A., Jones, C. E., Carpenter, L. J., and McFiggans, G. B.: Measurement and modelling of tropospheric reactive halogen species over the tropical Atlantic Ocean, Atmos. Chem. Phys., 10, 4611-4624, doi:10.5194/acp-10-46112010, 2010.

McFiggans, G., Plane, J. M., Allan, B. J., Carpenter, L. J., Coe, H., and O'Dowd, C.: A modeling study of iodine chemistry in the marine boundary layer, J. Geophys. Res.-Atmos., 105, 1437114385, 2000.

Mishra, S., Singh, V., Jain, A., and Verma, K. K.: Determination of iodide by derivatization to 4-iodo-N,N-dimethylaniline and gas chromatography-mass spectrometry, Analyst, 125, 459-464, 2000

Moore, R. M., Webb, M., Tokarczyk, R., and Wever, R.: Bromoperoxidase and iodoperoxidase enzymes and production of halogenated methanes in marine diatom cultures. J. Geophys. Res.Oceans, 101, 20899-20908, 1996.

O'Dowd, C. D. and Hoffmann, T.: Coastal new particle formation: a review of the current state-of-the-art, Environ. Chem., 2, 245 255,2005

Quack, B., Peeken, I., Petrick, G., and Nachtigall, K.: Oceanic distribution and sources of bromoform and dibromomethane in the Mauritanian upwelling, J. Geophys. Res.-Oceans, 112, C10006, doi:10.1029/2006JC003803, 2007.

Read, K. A., Mahajan, A. S., Carpenter, L. J., Evans, M. J., Faria, B. V. E., Heard, D. E., Hopkins, J. R., Lee, J. D., Moller, S. J., Lewis, A. C., Mendes, L., McQuaid, J. B., Oetjen, H., Saiz-Lopez, A., Pilling, M. J., and Plane, J. M. C.: Extensive halogen-mediated ozone destruction over the tropical Atlantic Ocean, Nature, 453, 1232-1235, 2008.
Roy, R.: Short-term variability in halocarbons in relation to phytoplankton pigments in coastal waters of the central eastern Arabian Sea, Estuar Coast. Shelf. S., 88, 311-321, 2010.

Roy, R., Pratihary, A., Narvenkar, G., Mochemadkar, S., Gauns, M., and Naqvi, S. W. A.: The relationship between volatile halocarbons and phytoplankton pigments during a Trichodesmium bloom in the coastal eastern Arabian Sea, Estuar Coast. Shelf. S., 95, 110-118, 2011.

Saiz-Lopez, A. and Plane, J. M.: Novel iodine chemistry in the marine boundary layer, Geophys. Res. Lett., 31,L04112, doi:10.1029/2003GL019215, 2004.

Saiz-Lopez, A., Plane, J. M. C., McFiggans, G., Williams, P. I., Ball, S. M., Bitter, M., Jones, R. L., Hongwei, C., and Hoffmann, T.: Modelling molecular iodine emissions in a coastal marine environment: the link to new particle formation, Atmos. Chem. Phys., 6, 883-895, doi:10.5194/acp-6-883-2006, 2006.

Sakamoto, Y., Yabushita, A., Kawasaki, M., and Enami, S.: Direct emission of $\mathrm{I}_{2}$ molecule and $\mathrm{IO}$ radical from the heterogeneous reactions of gaseous ozone with aqueous potassium iodide solution, J. Phys. Chem. A, 113, 7707-7713, 2009.

Schall, C., Heumann, K. G., and Kirst, G. O.: Biogenic volatile organoiodine and organobromine hydrocarbons in the Atlantic Ocean from $42^{\circ} \mathrm{N}$ to $72^{\circ} \mathrm{S}$, Fresen. J. Anal. Chem., 359, 298 305, 1997.

Schwehr, K. A. and Santschi, P. H.: Sensitive determination of iodine species, including organo-iodine for freshwater and seawater samples using high performance liquid chromatography and spectrophotometric detection, Anal. Chim. Acta, 482, 5971, 2003.

Thorenz, U. R., Kundel, M., Müller, L., and Hoffmann, T.: Generation of standard gas mixtures of halogenated, aliphatic, and aromatic compounds and prediction of the individual output rates based on molecular formula and boiling point, Anal. Bioanal. Chem., 404, 2177-2183, 2012.

van Bergeijk, S. A, Hernandez Javier, L., Heyland, A, Manchado, M., and Pedro Canavate J.: Uptake of iodide in the marine haptophyte Isochrysis sp. (T.ISO) driven by iodine oxidation, J. Phycol., 49, 640-647, 2013.

von Glasow, R. and Crutzen, P. J.: Tropospheric Halogen Chemistry, in: Treatise on Geochemistry Update1, Vol 4.02, 1-67, 2003.

Weisse, T., Grimm, N., Hickel, W., and Martens, P.: Dynamics of Phaeocystis pouchetii blooms in the Wadden Sea of Sylt (German Bight, North Sea), Estuar. Coast. Shelf. S., 23, 171-182, 1986.

Wong G. T. F. and Cheng X.-H.: Dissolved organic iodine in marine waters: Determination, occurrence and analytical implications, Mar. Chem., 59, 271-281, 1998.

Wong, G. T., Piumsomboon, A. U., and Dunstan, W. M.: The transformation of iodate to iodide in marine phytoplankton cultures, Mar. Ecol.-Prog. Ser., 237, 27-39, 2002. 